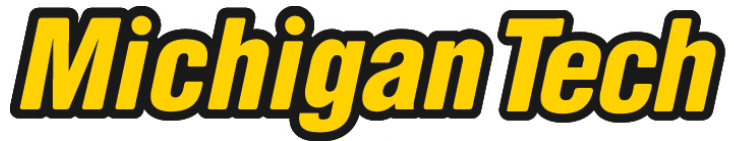 \\ Michigan Technological University Create the Future Digital Commons @ Michigan Tech
}

\section{Small-scale timber stand management techniques : a case study of woodlots in Isangati, Tanzania}

Paul D. Francis

Follow this and additional works at: https://digitalcommons.mtu.edu/etds

Part of the Forest Sciences Commons

Copyright 2012 Paul D. Francis

\section{Recommended Citation}

Francis, Paul D., "Small-scale timber stand management techniques : a case study of woodlots in Isangati, Tanzania", Master's Thesis, Michigan Technological University, 2012.

https://doi.org/10.37099/mtu.dc.etds/176

Follow this and additional works at: https://digitalcommons.mtu.edu/etds

8 Part of the Forest Sciences Commons 
Farm System Diagram - Isangati, Tanzania

This farm system diagram outline follows the methods described in Beets (1990).

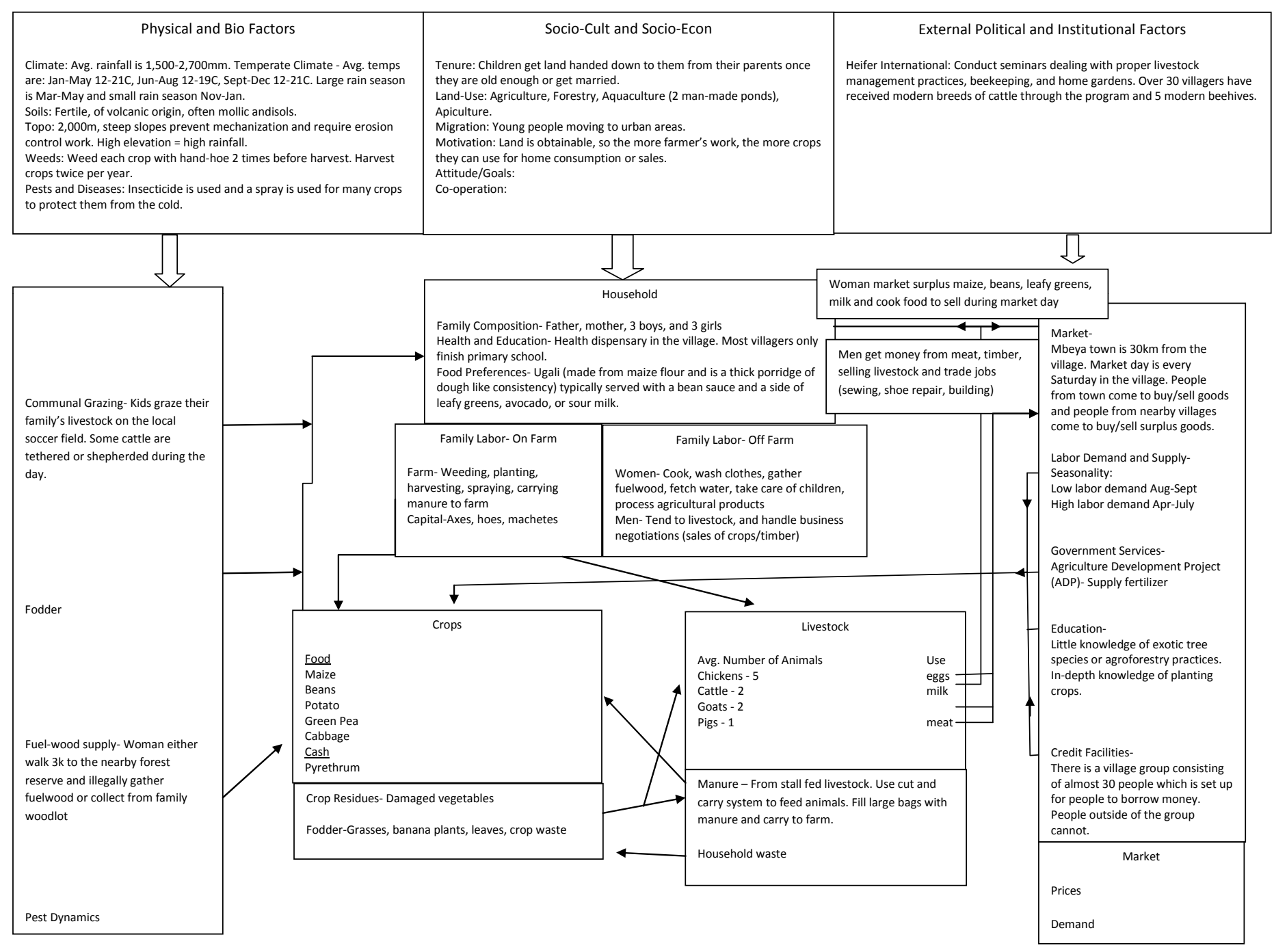

